\title{
Protective effect of Pseudomonas fluorescens as a probiotic in controlling fish pathogens
}

\author{
Nour Eissa ${ }^{1,}$, EISayed Abou El-Gheit ${ }^{1}$, Adel A. Shaheen ${ }^{2}$ \\ ${ }^{1}$ Aquatic Diseases Laboratory, Aquaculture Division, National Institute of Oceanography and Fisheries, 101 Kaser El-Aini Street, Cairo \\ 11516, Egypt \\ ${ }^{2}$ Department of Fish Diseases and Management, Faculty of Veterinary Medicine, Benha University, Moshtohor, Toukh, 13736, Egypt
}

\section{Email address:}

noureissa@live.com (N. Eissa)

\section{To cite this article:}

Nour Eissa, ElSayed Abou El-Gheit, Adel A. Shaheen. Protective Effect of Pseudomonas Fluorescens as a Probiotic in Controlling Fish Pathogens. American Journal of BioScience. Vol. 2, No. 5, 2014, pp. 175-181. doi: 10.11648/j.ajbio.20140205.12

\begin{abstract}
The use of Pseudomonas fluorscens isolates as biological control agents against two fish pathogens; Pseudomonas angulliseptica and Streptococcus faecium in Nile tilapia were investigated in vivo and vitro. Pseudomonas fluorscens biovars I, II \& III were tested in vitro using the agar diffusion method and showed effectiveness in inhibiting growth of $P$. angulliseptica and Strep. faecium. Pseudomonas fluorscens biovar II was the most effective with largest inhibition zones against both pathogens. For oral administration, $P$. fluorscens biovars were incorporated into the mixed feed diet. A significant reduction in mortality rate and a significant increase in hematological parameters, total protein, and globulin in fish groups fed Pseudomonas fluorscens incorporated diet following challenge by P. angulliseptica and Strep. faecium. It could be concluded that $P$. fluorescens has a protective effect against different Nile Tilapia pathogens and could be used as a probiotic bacteria and an eco-friendly alternative measure to chemical antimicrobials and further research studies to clarify its protective mechanisms on cellular and molecular levels.
\end{abstract}

Keywords: Probiotics, Pseudomonas, Fish Diseases, Biological Control, Hematological Parameters

\section{Introduction}

Aquaculture is an emerging industry as one of the promising enterprises for providing nutritional and food security to humans and supplying the protein demands since there are some critical problems with other resources. However, most of the intensive aquaculture farms have been facing major problems resulted from outbreaks caused by several pathogens, especially bacterial ones which are leading to high mortality and limiting the aquaculture industry expansion. Pseudomonas anguilliseptica is an opportunistic pathogen for many cultured fish species in marine and brackish waters worldwide [1] and can cause certain outbreaks under stressful conditions and considered the most significant pathogen among pseudomonas species for cultured fish [2]. Pseudomonas anguilliseptica was originally described as the bacterial causative agent of "Sekiten-byo" (red spot disease) in pond-cultured Japanese eel, Anguilla japonica [3] and in Finland; it was identified as the etiology of several disease out-breaks in several species of farmed salmonid fish [4]. In Egypt, $P$. anguilliseptica was isolated from naturally infected tilapia $[5,6]$. Fish streptococcosis is a reemerging disease affecting a variety of wild and cultured fish throughout the world and a limiting factor for aquaculture industry [7]. Streptococcosis have triggered significant economic losses in the aquaculture industry worldwide causing high mortality, reduced growth, and unmarketable appearance. Streptococcus affects a wide range of cultured fish species, including hybrid striped bass, tilapia [8], rabbit fish, Siganus canaliculatus [9], rainbow trout, Oncorhynchus mykiss [10], red drum, Sciaenops ocellatus [11] and European sea bass, Dicentrarchus labrax [12]

The increased public awareness of the negative drawbacks caused by over-exposure to synthetic chemicals as well as emerging antimicrobial resistance led to search for alternatives and unique solutions such as organic and synthetic chemical-free food products. To promote organic fish production, it is necessary to develop antibacterial treatments that are based on materials from natural sources. Probiotic bacteria, a live micro-organism that when managed in adequate amounts can confer a health benefit on the host [13], could protect fish and other aquatic animals through 
different ways such as antagonizing the pathogens for living space, adhesion sites, energy and essential nutrients, producing inhibitory compounds and improving the immune response of the fish [14]. Probiotic bacteria has the ability to adhere to and colonize into the gut and so form a barrier against pathogenic microorganisms and/or to stimulate the host's immune system and this consider the most common concern about the mode of action [15]. In particular, innate immunity has been shown to be affected by feeding fish with probiotic [15]. Non-pathogenic pseudomonas can be used for control of some bacterial pathogens [2] in vivo and in vitro antibacterial activity against Aeromonas hydrophila $[16,17$, 18], Aeromonas salmonicida [19], Staphylococcus aureus and Aeromonas sobria [20], Saprolegnia and other fungi [21, 22], Vibrio [23] and Flavobacterium psychrophilum [24].

Therefore, this study was designed as initial study to test the capability of non-pathogenic Pseudomonas fluorescens Biovars to control and prevent Pseudomonas anguilliseptica and Streptococcus faecium which are considered important pathogens in many cultured and wild fish species in vitro and in vivo. And, the main objective of this study was designed to prevent, control or limit the virulence of these pathogens especially with using the beneficial bacteria as a feed additive. Having native probiotic strains is a big advantage toward the successful and effective probiotic application and generally in the aquaculture industry, the concept is prophylaxis is always better than treatment.

\section{Materials and Method}

\subsection{Bacteria and Growth Medium}

Non-pathogenic Pseudomonas fluorescens Biovars I, II \& III were previously isolated from naturally infected tilapia, identified and their safety tested by published work $[5,18]$. Pseudomonas anguilliseptica was evaluated for its pathogenicity by [5] and Streptococcus faecium was obtained from Aquatic Diseases Lab., National Institute of Oceanography \& Fisheries (NIOF), Egypt. Bacteria were kept frozen in $15 \%$ glycerol, $85 \%$ saline solution in aliquots, at $-80{ }^{\circ} \mathrm{C}$ for further use.

\subsection{In-Vitro Antimicrobial Activity}

In vitro antimicrobial activity was assessed using the agar diffusion method and the inhibition zone was determined according to [25]. The three P. fluorescens biovar I, II and III isolates were inoculated in the center of culture plates, containing tryptic soya agar and incubated at $30{ }^{\circ} \mathrm{C}$ for $24 \mathrm{~h}$. Then, a fresh Tryptic Soya Broth (TSB) containing the pathogenic Pseudomonas anguilliseptica and another fresh TSB containing Streptococcus faecium were spread over the plates, previously inoculated with the tested bacteria. Incubation at $30{ }^{\circ} \mathrm{C}$ for $24 \mathrm{~h}$ and checked for the appearance of inhibition zones and their sizes were recorded.

\subsection{Experimental Fish}

A total of 270 healthy Nile tilapia $(70 \pm 5 \mathrm{~g} /$ fish $)$ were obtained from Fish Farm Research Station, NIOF, Egypt. Fish were randomly stocked into nine indoor glass aquaria at a rate of 30 fish / aquarium and acclimatized for two weeks prior to experiments, at $22 \pm 1{ }^{\circ} \mathrm{C}$ and subjected to $12 \mathrm{~h}$ light/ $12 \mathrm{~h}$ dark. Fish were fed a commercial tilapia diet contains on protein $26 \%$ and Fat $3 \%$ (Zoocontrol $^{\circledR}$, Egypt) twice daily at a rate of $2 \%$ of fish body weight during acclimation and experiment. To verify that the fish were free of bacterial infection, fish were randomly sampled and their livers and kidneys were aseptically streaked on Tryptic Soya Agar and incubated at $25^{\circ} \mathrm{C}$ for $48 \mathrm{~h}$.

\subsection{Water Quality Evaluation}

Aquaria water quality parameters were monitored daily. Dissolved oxygen was measured with a dissolved oxygen meter $\left(\mathrm{YSI}^{\circledR}\right.$ Incorporated, OH, USA). Ammonia and nitrites were measured using visocolor kits (MachereyNagel $^{\circledR}$, Germany). Temperature, Oxygen, ammonia and nitrite levels were maintained at $22 \pm 1{ }^{\circ} \mathrm{C}, 6.8 \mathrm{mg} / \mathrm{l}, 0.1 \pm$ 0.01 and $1 \pm 0.5 \mathrm{mg} / \mathrm{l}$, respectively. The aquaria were cleaned daily by siphoning off two thirds of the water and replacing it with fresh water.

\subsection{Feed Preparation}

Incorporated diets with non-pathogenic P. fluorescens were prepared according to the method described by [14]. Bacterial colonies (P. fluorescens biovars I, II, III) were grown on TSB, harvested by centrifugation at 1000 RPM for $10 \mathrm{~min}$, washed with saline and re-suspended in saline to $10^{10}$ cells $\mathrm{mL}^{-1}$. Thereafter, volumes were mixed thoroughly in $100 \mathrm{~g}$ of the commercial dry feed contains on protein $26 \%$ and Fat $3 \%$ (Zoocontrol $^{\circledR}$, Egypt) to achieve a dose equivalent to $10^{8}$ bacterial cells $\mathrm{g}^{-1}$ of feed.

\subsection{Feeding Experiment}

To study the effect of $P$. fluorescens against $P$. anguilliseptica and Streptococcus faecium infection in vivo, the following feeding experiment was conducted. Fish were fed with incorporated diet with non-pathogenic $P$. fluorescens biovars for 7 days then injected intra-peritoneal with pathogenic $P$. anguilliseptica at dose $3 \times 10^{7} \mathrm{CFU} / \mathrm{ml} /$ fish as its LD50 2-4 x $10^{7} \mathrm{CFU} / \mathrm{ml} /$ fish and Streptococcus faecium at dose $3 \times 10^{8} \mathrm{CFU} / \mathrm{ml} /$ fish which has LD50 $1.5-$ $4 \times 10^{8} \mathrm{CFU} / \mathrm{ml} /$ fish. Infected and non-infected control groups were used as positive and negative experimental control groups. Fish continued to be fed with the nonpathogenic $P$. fluorescens incorporated diet for another 7 days. Behavioral alterations, feeding response, and mortality for all experimental groups were examined and recorded daily. Dead fish were removed daily and subjected to bacteriological examination for presence of pathogens. Groups and dose of inoculation were represented and 
tabulated (Table 1).

\subsection{Hematological Analysis}

At the end of the experiment, 10 fish from each aquarium were anaesthetized and blood samples were collected from the caudal vein into heparinized tubes. Blood samples were used for determination of RBCs, $\mathrm{Hb}$,
PCV, WBCs and differential leukocytic count according to [26]. And, Serum samples were obtained by blood centrifugation at 3000 RPM for 15 minutes for estimation of the total protein content calorimetrically according to method described by [27] and albumin content by a colorimetric method at wave length $550 \mathrm{~nm}$ according to [28].

Table 1. Feeding experiment design to evaluate in vivo antimicrobial efficiency of isolated non-pathogenic Pseudomonas fluorescens.

\begin{tabular}{|c|c|c|c|c|c|c|}
\hline \multirow{2}{*}{$\begin{array}{l}\text { Groups } \\
\text { Group No. }\end{array}$} & \multicolumn{3}{|c|}{ Inoculating organisms } & \multicolumn{3}{|c|}{ Inoculating bacteria (pathogenic) } \\
\hline & Fish No. & Species of bacteria & Dose & Route & Species of bacteria & Dose \\
\hline \multirow{4}{*}{$1^{\text {st }}$ group } & 30 & P. fluorescens biovar I & $10^{8}$ cells $/ \mathrm{g}$ & Feeding & $P$. anguilliseptica & $0.1 \mathrm{ml}\left(3 \times 10^{7} \mathrm{CFU}\right)$ \\
\hline & 30 & P. fluorescens biovar II & $10^{8}$ cells $/ \mathrm{g}$ & Feeding & P. anguilliseptica & $0.1 \mathrm{ml}\left(3 \times 10^{7} \mathrm{CFU}\right)$ \\
\hline & 30 & P. fluorescens biovar III & $10^{8}$ cells $/ \mathrm{g}$ & Feeding & P. anguilliseptica & $0.1 \mathrm{ml}\left(3 \times 10^{7} \mathrm{CFU}\right)$ \\
\hline & 30 & Control infected & Normal diet & Feeding & P. anguilliseptica & $0.1 \mathrm{ml}\left(3 \times 10^{7} \mathrm{CFU}\right)$ \\
\hline \multirow{4}{*}{$2^{\text {nd }}$ group } & 30 & P. fluorescens biovar I & $10^{8}$ cells $/ \mathrm{g}$ & Feeding & Strep. faecium & $0.1 \mathrm{ml}\left(3 \times 10^{8} \mathrm{CFU}\right)$ \\
\hline & 30 & P. fluorescens biovar II & $10^{8}$ cells $/ \mathrm{g}$ & Feeding & Strep. faecium & $0.1 \mathrm{ml}\left(3 \times 10^{8} \mathrm{CFU}\right)$ \\
\hline & 30 & P. fluorescens biovar III & $10^{8}$ cells $/ \mathrm{g}$ & Feeding & Strep. faecium & $0.1 \mathrm{ml}\left(3 \times 10^{8} \mathrm{CFU}\right)$ \\
\hline & 30 & Control infected & Normal diet & Feeding & Strep. faecium & $0.1 \mathrm{ml}\left(3 \times 10^{8} \mathrm{CFU}\right)$ \\
\hline $3^{\text {rd }}$ group & 30 & Control non infected & Normal diet & Feeding & Saline $0.9 \%$ & $0.1 \mathrm{ml}$ \\
\hline
\end{tabular}

\subsection{Statistical Analysis}

Analysis of variance (One way ANOVA) and Duncan's multiple range test (DMRT) were carried out to determine differences between treatments at probability level $P>0.01$ according to [29]. All the statistical analysis was done by using the software program SPSS (version 22).

\section{Results and Discussion}

The antibacterial effect of probiotic bacteria may be due to either individual or joint production of antibiotics, bacteriocins, siderophores [30], lysozymes and proteases and alteration of $\mathrm{pH}$ by organic acid production [31]. In present study, in vitro evaluation showed that nonpathogenic Pseudomonas fluorescens biovar I, II and III had an antagonist effect against Pseudomonas angulliseptica and Streptococcus faecium in fish. In vitro assay, $P$. fluorescens biovars had antibacterial activity against both bacterial pathogens Pseudomonas angulliseptica and Streptococcus faecium. And $P$. fluorescens biovar II resulted in a larger inhibition zone (6 $\& 5 \mathrm{~mm})$ than biovar I ( 3 \& $3 \mathrm{~mm})$ and III $(4 \& 3 \mathrm{~mm})$ against $P$. angulliseptica and Streptococcus faecium respectively. Previous studies have the same results against different pathogenic organisms such as $P$. fluorescens had an antimicrobial effect in vitro on microbiological plates in the laboratory against Aeromonas hydrophila and Aeromonas salmonicida [16-18, 32]. Pseudomonas fluorescens's antimicrobial effect in vitro may be attributed to the production of several antibiotic-like substances as bacteriocins and a phenazine antibiotic [33], non-nitrogencontaining compound [34] and siderophores production which mediated competition for iron $[20,35,36]$.

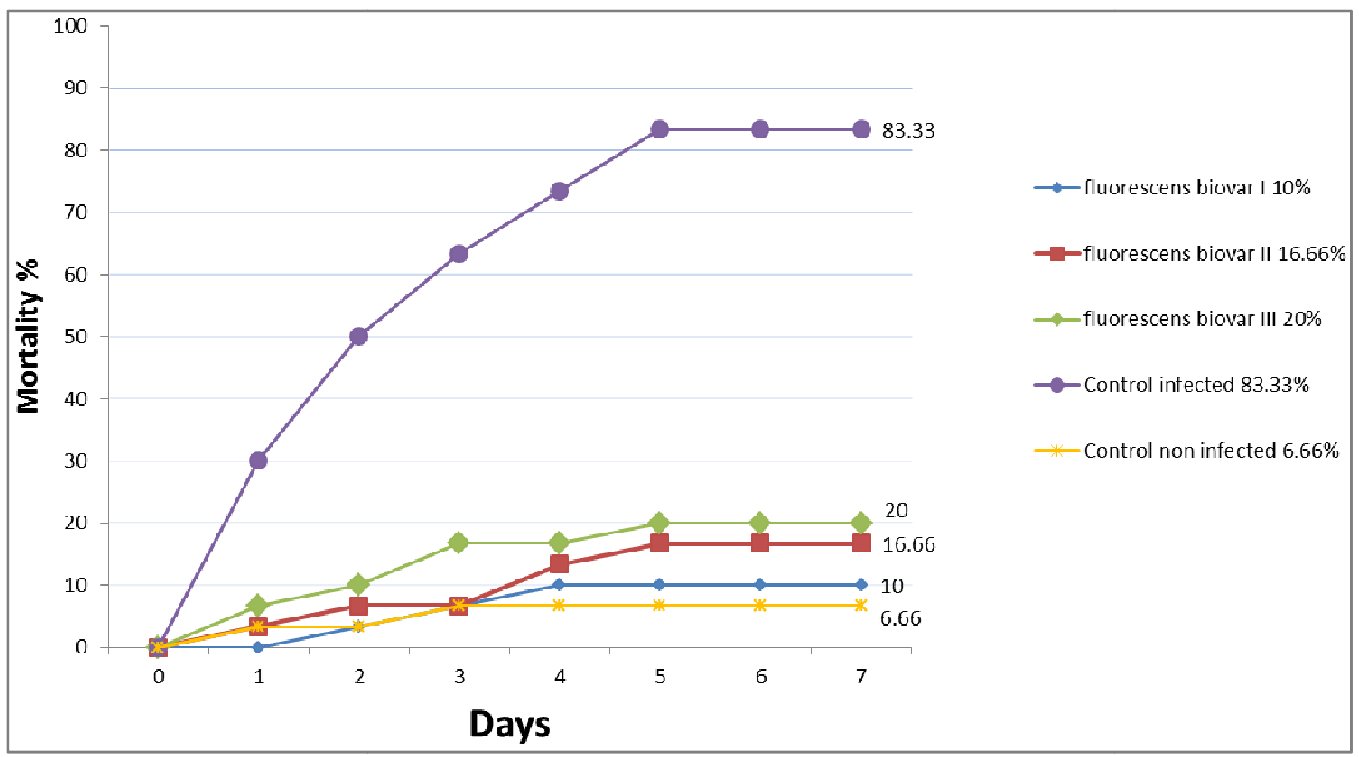

Figure 1A. Cumulative mortality rate of $O$. niloticus fed a diet containing $10^{8}$ cells $/ g$ P. fluorescens biovar I, II \& III for 7 successive days and then challenged $1 / P$ with $0.1 \mathrm{ml}\left(3 \times 10^{7}\right.$ cells $)$ of $P$. anguilliseptica 


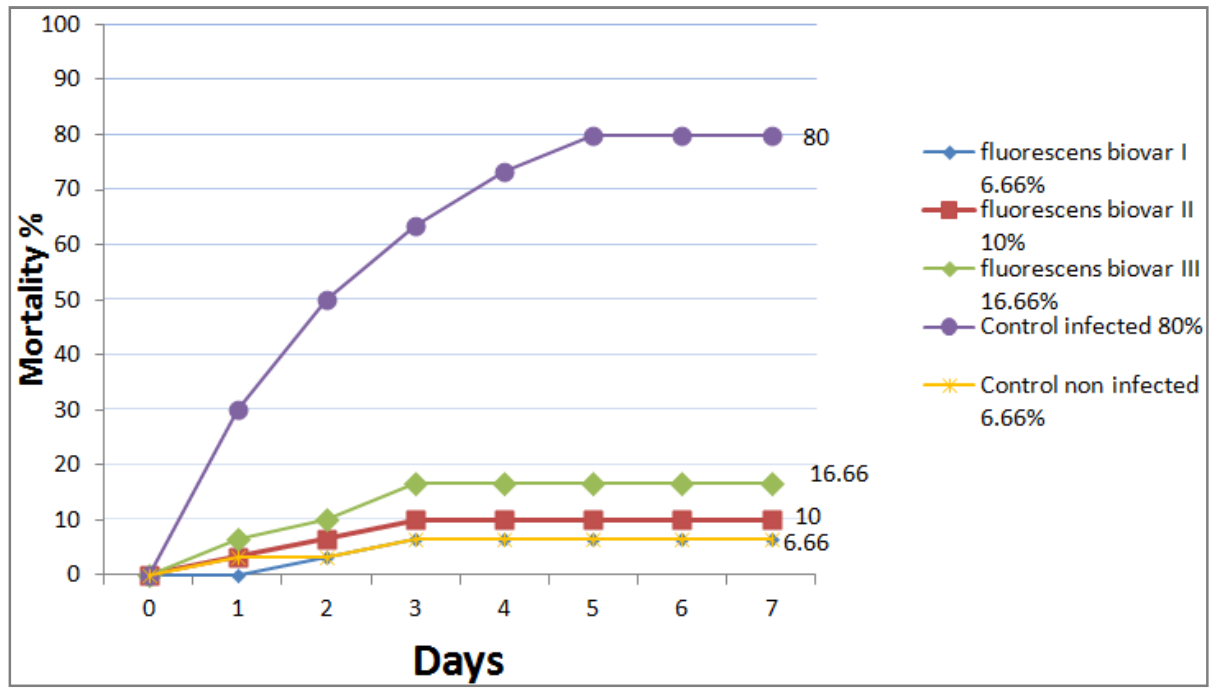

Figure 1B. Cumulative mortality rate of $O$. niloticus fed a diet containing $10^{8}$ cells $/ g$ P. fluorescens biovar I, II \& III for 7 successive days and then challenged I/P with $0.1 \mathrm{ml}\left(3 \times 10^{8}\right.$ cells) of Strept. faecium

Table 2. Hematological parameters of fish groups challenged by P. angulliseptica. Means with the same letter within a column are not significantly different $(P<0.01)$.

\begin{tabular}{|c|c|c|c|c|c|c|c|c|c|}
\hline Groups & $\mathrm{Hb} \mathrm{g} / 100 \mathrm{ml}$ & PCV \% & $\begin{array}{l}\text { RBCs } \\
106 / \mathrm{mm} 3\end{array}$ & $\begin{array}{l}\text { WBCs } \\
103 / \mathrm{mm} 3\end{array}$ & $\begin{array}{l}\text { Lymphocytes } \\
103 / \mathrm{mm} 3\end{array}$ & $\begin{array}{l}\text { Monocytes } \\
103 / \mathrm{mm} 3\end{array}$ & $\begin{array}{l}\text { Protein } \\
\text { g/100ml }\end{array}$ & $\begin{array}{l}\text { Albumin } \\
\text { g/100ml }\end{array}$ & $\begin{array}{l}\text { Globulin } \\
\text { g/100ml }\end{array}$ \\
\hline Control & $4.3 \pm 0.066^{\mathrm{c}}$ & $15.2 \pm 0.13^{c}$ & $1.31 \pm 0.014^{\mathrm{c}}$ & $58.2 \pm 0.97^{\mathrm{c}}$ & $47.33 \pm 0.57^{\mathrm{d}}$ & $5.61 \pm 0.036^{\mathrm{d}}$ & $2.75 \pm 0.13^{c}$ & $0.75 \pm 0.04^{\mathrm{a}}$ & $2.06 \pm 0.15^{\mathrm{d}}$ \\
\hline $\begin{array}{l}P . \text { fluorescens } \\
\text { biovar I }\end{array}$ & $5.21 \pm 0.18^{b}$ & $21.95 \pm 0.3^{\mathrm{b}}$ & $1.47 \pm 0.035^{b}$ & $69.65 \pm 0.59^{b}$ & $52.66 \pm 0.68^{c}$ & $10.25 \pm 0.29^{c}$ & $3.01 \pm 0.085^{\mathrm{b}}$ & $0.68 \pm 0.021^{b}$ & $2.62 \pm 0.60^{c}$ \\
\hline $\begin{array}{l}P . \text { fluorescens } \\
\text { biovar II }\end{array}$ & $5.42 \pm 0.16^{\mathrm{a}}$ & $22.33 \pm 0.21^{\mathrm{a}}$ & $1.55 \pm 0.17^{\mathrm{a}}$ & $71.33 \pm 0.89^{\mathrm{a}}$ & $53.04 \pm 0.73^{b}$ & $11.66 \pm 0.35^{\mathrm{a}}$ & $3.55 \pm 0.36^{\mathrm{a}}$ & $0.56 \pm 0.07^{\mathrm{c}}$ & $3.21 \pm 0.022^{\mathrm{a}}$ \\
\hline $\begin{array}{l}\text { P. fluorescens } \\
\text { biovar III }\end{array}$ & $5.12 \pm 0.13^{b}$ & $23.25 \pm 0.42^{\mathrm{a}}$ & $1.54 \pm 0.13^{\mathrm{a}}$ & $71.88 \pm 0.61^{\mathrm{a}}$ & $55.11 \pm 0.56^{\mathrm{a}}$ & $10.88 \pm 0.45^{\mathrm{b}}$ & $3.12 \pm 0.045^{\mathrm{b}}$ & $0.54 \pm 0.017^{\mathrm{d}}$ & $3.01 \pm 0.046^{\mathrm{b}}$ \\
\hline
\end{tabular}

Table 3. Hematological and physiological parameters of fish groups challenged by Strep. faecium. Means with the same letter within a column are not significantly different $(P<0.01)$.

\begin{tabular}{|c|c|c|c|c|c|c|c|c|c|}
\hline Groups & $\mathrm{Hb} \mathrm{g} / 100 \mathrm{ml}$ & PCV \% & $\begin{array}{l}\text { RBCs } \\
10^{6} / \mathrm{mm}^{3}\end{array}$ & $\begin{array}{l}\text { WBCs } \\
10^{3} / \mathrm{mm}^{3}\end{array}$ & $\begin{array}{l}\text { Lymphocytes } \\
10^{3} / \mathrm{mm}^{3}\end{array}$ & $\begin{array}{l}\text { Monocytes } \\
10^{3} / \mathrm{mm}^{3}\end{array}$ & $\begin{array}{l}\text { Protein } \\
\text { g/100ml }\end{array}$ & $\begin{array}{l}\text { Albumin } \\
\text { g/100ml }\end{array}$ & $\begin{array}{l}\text { Globulin } \\
\text { g/100ml }\end{array}$ \\
\hline Control & $4.3 \pm 0.066^{\mathrm{c}}$ & $15.2 \pm 0.13^{\mathrm{d}}$ & $1.31 \pm 0.014^{\mathrm{d}}$ & $58.2 \pm 0.97^{d}$ & $47.33 \pm 0.57^{d}$ & $5.61 \pm 0.036^{c}$ & $2.75 \pm 0.13^{d}$ & $0.75 \pm 0.04^{d}$ & $2.06 \pm 0.15^{\mathrm{c}}$ \\
\hline $\begin{array}{l}\text { P. fluorescens } \\
\text { biovar I }\end{array}$ & $5.01 \pm 0.13^{b}$ & $20.66 \pm 0.01^{c}$ & $1.41 \pm 0.029^{\mathrm{c}}$ & $68.88 \pm 0.46^{\mathrm{c}}$ & $51.94 \pm 0.83^{\mathrm{c}}$ & $10.07 \pm 0.35^{\mathrm{b}}$ & $3.21 \pm 0.04^{\mathrm{c}}$ & $0.65 \pm 0.045^{\mathrm{a}}$ & $2.83 \pm 0.70^{\mathrm{b}}$ \\
\hline $\begin{array}{l}\text { P. fluorescens } \\
\text { biovar II }\end{array}$ & $5.11 \pm 0.11^{\mathrm{a}}$ & $21.48 \pm 0.33^{\mathrm{b}}$ & $1.53 \pm 0.14^{\mathrm{a}}$ & $71.02 \pm 0.93^{\mathrm{a}}$ & $53.13 \pm 0.37^{\mathrm{b}}$ & $10.96 \pm 0.65^{\mathrm{a}}$ & $3.42 \pm 0.24^{\mathrm{b}}$ & $0.58 \pm 0.01^{\mathrm{c}}$ & $3.02 \pm 0.075^{\mathrm{a}}$ \\
\hline $\begin{array}{l}\text { P. fluorescens } \\
\text { biovar III }\end{array}$ & $5.14 \pm 0.10^{\mathrm{a}}$ & $22.25 \pm 0.40^{\mathrm{a}}$ & $1.50 \pm 0.16^{\mathrm{b}}$ & $70.12 \pm 0.43^{b}$ & $54.01 \pm 0.86^{\mathrm{a}}$ & $10.89 \pm 0.63^{\mathrm{a}}$ & $3.67 \pm 0.052^{\mathrm{a}}$ & $0.60 \pm 0.072^{b}$ & $3.0 \pm 0.044^{\mathrm{a}}$ \\
\hline
\end{tabular}

The fish feeding experiment exhibited lower mortality rate in fish groups fed a $P$. fluorescens biovars incorporated diet than infected control groups. The fish groups fed P. fluorescens biovar I, II \& III and challenged by $P$. angulliseptica (Figure 1A), resulted in 10, 16.66 and 20\% cumulative mortality respectively, and these results could be attributed to many theories for instance pseudomonas produces antibiotic metabolites, which are inhibitory for both gram-negative and gram-positive bacteria [37] and another research study reported that pseudomonas strain of fish origin inhibited a number of pseudomonas strains involved in meat spoilage [38]. Correspondingly, aquatic pseudomonads are often antagonistic against other microorganisms, including fish-pathogenic bacteria and fish-pathogenic fungi, and the antibacterial ability of pseudomonas species may protect host fish against pathogenic bacteria [31]. In 2006, the authors concluded that pseudomonas species PS 102 could be employed as a potential biological control agent in shrimp and prawn aquaculture systems for management and control of bacterial infections [39]. The fish groups fed with $P$. fluorescens biovar I, II \& III integrated diet and challenged by Strep. faecium (Figure, 1B) exhibited mortality rates of $6.66,10$ and $16.66 \%$, respectively, while the control infected group did not resist Strep. faecium while the control infected group had a $83.33 \%$ and $6.66 \%$ in control non-infected group mortality rate. These results agreed with that marine pseudomonas species associated with soft coral have antibacterial activity against Streptococcus equi [40] and this might be attributed to some of pseudomonas bioactive substances are antimicrobial properties [41]. Additionally, pseudomonas gave an excellent antibacterial 
activity and inhibited growth of clinical isolates as well as indigenous marine bacteria, but in other hand did not give activity against Streptococcus [42]. Pseudomonas fluorescens antimicrobial effect may be resulted from antibacterial substances produced by pseudomonas which have diverse mechanisms of action; some affect the bacterial cell membrane causing bacterial cell lysis, whereas the others act as acetyl-CoA carboxylase and nitrous oxide synthesis inhibitors [41]. Another probability, It also may stimulate the appetite and improve nutrition through vitamins production, detoxification of injurious compounds in the diet, and breakdown of indigestible components [14]. As companion, siderophore production is also a possible action used by Pseudomonas to counteract and constrain pathogens involved in plant diseases [43], in fish, rainbow trout [24] and it was concluded by that pathogens with potential low iron uptake should be more influenced with siderophore assembly of the probiotic used against them.

Hematological and physiological analysis showed that groups fed on a Pseudomonas fluorescens biovars incorporated diet had a significant increase in RBCs count, $\mathrm{PCV} \%, \mathrm{Hb}$ content, WBCs, lymphocytes and monocytes levels in comparison to the control group (Table $2 \& 3$ ). This was attributed to those non-pathogenic bacteria which have probiotic effects, could stimulate hemopiotic response resulting in raising hematological parameters [14, 18, 44]. The total protein and globulin (Table $2 \& 3$ ) were higher than the control group in all groups treated with Pseudomonas fluorescens and same results were reported by $[17,18]$. The significant increase in total protein and globulin and decrease in albumin level accredited to the modulator effect of Pseudomonas fluorescens on liver cells resulting in activation of the anabolic capacity of hepatocytes to produce blood proteins, especially globulin [15].

Drug resistance development in bacteria and the accumulation of chemicals in the environment have led to strict regulations that limit the use of antibiotics and chemotherapy in aquaculture industry $[45,46]$ in many countries to avoid emerging new bacterial resistant strains. This study showed a small picture about the potential use of non-pathogenic bacteria as a progressive new solution for controlling fish pathogens and for organic fish culture which could potentially be used as alternatives to chemotherapy. Afterwards, it can be concluded that probiotics could be a new eco-friendly alternative measure to control fish diseases for sustainable aquaculture. Further studies will focus on manipulation of commensal microbiota to produce organic products to compete with fish pathogens and identify the protective mechanisms of non-pathogenic pseudomonas strains on cellular and molecular levels.

\section{Acknowledgment}

This work was supported by National Institute of Oceanography and Fisheries and Cultural Affairs and
Missions sector, Ministry of Higher Education and Scientific Research, Egypt. Salaries and research support were provided by governmental funds appropriated to National Institute of Oceanography \& Fisheries, Egypt.

\section{References}

[1] Daly, J. G. (1999). Other bacterial pathogens. Pages 577-598 in P. T. K. Woo and D. W. Bruno, editors. Fish Diseases and Disorders. Vol. 3, Viral, Bacterial and Fungal infections. CABI Publishing, London, New York.

[2] Austin, B. and Austin, D. A. (2007). Bacterial fish pathogens. Diseases of farmed and wild fish. SpringerPraxis Publishing, Ltd., United Kingdom.

[3] Wakabayashi, H. and Egusa, S. (1972). Characteristics of Pseudomonas sp. From an epizootic of pond-cultured eels (A. japonica). Bulletin of the Japanese Society for the Science of Fish 38:577-587.

[4] Wiklund, T. and Dalsgaard, I. (1987). Diseased outbreaks caused by $P$ s. anguilliseptica in finnish fish farms. In: Stenmark, A.; Malmberg, G. (Eds.), Parasites and Diseases in Natural Waters and Aquaculture in Nordic Countries, Swedish Museum of Natural History, Stockholm, p. 131 (Abstract).

[5] Eissa, N. Abou El-Ghiet, E. Shaheen, A. A. and Abbass, A. (2010). Characterization of pseudomonas species isolated from Tilapia (Oreochromis niloticus) in Qaroun and WadiEl-Rayan lakes, Egypt. Global Veterinaria 5 (2):116-12.

[6] El-Hady, M. and Samy A. A. (2011). Molecular typing of pseudomonas species isolated from some cultured fishes in Egypt. Global Veterinaria 7 (6):576-580.

[7] Romalde, J.L. and Toranzo, A. E. (2002). Molecular approaches for the study and diagnosis of salmonid streptococcosis: C.O. Cunningham (Ed.), Molecular diagnosis of salmonid diseases, Kluwer Academic Publ, Netherlands, 8: 211-223

[8] Shoemaker C, Klesius P (1997) Streptococcal disease problems and control a review. In: Fitzsimmons, K. (Ed.) Tilapia Aquaculture, vol. 2. Northest Regional Agricultural Engineering Service, Ithaca, NY, 671- 682.

[9] Yuasa, K. Kitancharoen, N. Kataoka, Y. Al-Murbaty, F. A. (1999). Streptococcus iniae the causative agent of mass mortality in rabbitfish Siganus canaliculatus in Bahrain. Journal of Aquatic Animal Health 11:87-93.

[10] Eldar A, Horvitcz A, Bercovier H (1997) Development and efficacy of a vaccine against Streptococcus iniae infection in farmed rainbow trout. Veterinary Immunology and Immunopathology 56:175-183.

[11] Eldar A, Perl S, Frelier PF, Bercovier H (1999) Red drum Sciaenops ocellatus mortalities associated with Streptococcus iniae infection. Disease of Aquatic Organism 36:121-127.

[12] Colorni, A. Diamant, D. Eldar, A. Kvitt, H. and Zlotkin, A. (2002). Streptococcus iniae infections in Red Sea cagecultured and wild fishes. Disease of Aquatic Organism 49:165- 170 . 
[13] FAO/WHO (2001). Health and nutritional properties of probiotics in food including powder milk with live lactic acid bacteria. Report of Joint Food and Agriculture Organization of the United Nations/World Health (FAO/WHO) Expert Consultation Report on Evaluation of Health and Nutritional Properties of Probiotics in Food Including Powder Milk with Live Lactic Acid Bacteria, pp. 1-34. Córdoba, Argentina: FAO/WHO.

[14] Irianto, A. and Austin, B. (2002). Use of dead probiotics to control furunculosis in rainbow trout, Oncorhynchus mykiss (Walbaum). Journal of Fish Disease 25:333-342.

[15] Nayak, S. K. (2010). Probiotics and immunity: A fish perspective. Fish and Shellfish Immunology 29:2-14.

[16] Das, B. K. Samal, S. K. Samantaray, B.R. Sethi, S. Pattnaik, P. and Mishra, B. K. (2006). Antagonistic activity of cellular components of Pseudomonas species against Aeromonas hydrophila. Aquaculture 253:17-24.

[17] Abd El-Rhman, A. M. Khattab, Y. E. and Shalaby, A. E. (2009). Micrococcus luteus and Pseudomonas species as probiotics for promoting the growth performance and health of Nile tilapia, Oreochromis niloticus. Fish and Shellfish Immunology 27:175-180.

[18] Eissa, N. and Abou El-Ghiet, E. N. (2011). Efficacy of Pseudomonas fluorescens as biological control agents against Aeromonas hydrophila infection in Oreochromis niloticus. World Journal of Fish and Marine Sciences. 3 (6):564-569, 201.

[19] Smith, P. and Davey, S. (1993). Evidence for the competitive exclusion of Aeromonas salmonicida from fish with stress inducible furunculosis by fluorescent pseudomonad. Journal of Fish Disease 16 (6):521-524.

[20] Gram, L. (1993). Inhibitory effect against pathogenic and spoilage bacteria of Pseudomonas strains isolated from spoiled and fresh fish. Applied and Environmental Microbiology 59:2197-2203.

[21] Bly, J. E. Quiniou, S. M. Lawson, L. A. and Clem, L. W. (1997). Inhibition of Saprolegnia pathogenic for fish by Pseudomonas fluorescens. Journal of Fish Disease 20:35-40.

[22] Hecker M, Engelmann S, Cordwell SJ (2003) Proteomics of Staphylococcus aureus current state and future challenges. Journal of Chromatography B Analytical Technologies in the Biomedical and Life Sciences 787: 179-195.

[23] Alavandi, S. V. Vijayan, K. K. Santiago, T.C. Poornima, M. Jithendran, K. P. Ali S. A. and Rajan, J. S. (2004). Evaluation of Pseudomonas sp. PM 11 and Vibrio fluvialis PM 17 on immune indices of tiger shrimp, (Penaeus monodon). Fish and Shellfish Immunology 17:115-120.

[24] Korkea-aho, T.L. Heikkinen, J. Thompson, K. D. von Wright, A. and Austin, B. (2011). Pseudomonas sp. M174 inhibits the fish pathogen Flavobacterium psychrophilum. Journal of Applied Microbiology, 111: 266-277.

[25] Ruiz, C.M. Roman. G. and Sánchez, J. L. (1996). A marine bacterial strain effective in producing antagonisms of other bacteria. Aquaculture International 4:289-291.

[26] Schalm, O. (1986). Schalm's Veterinary Hematology, $4^{\text {th }}$ Edition, 524.

[27] Henry, R. (1964). Colorimetric determination of total protein. In: Clinical Chemistry. New York: Harper and Row
Publ. pp. 220-225.

[28] Dumas, B.T. and Biggs, H.G. (1972). Standard methods of clinical chemistry. Academic Press, New York, 344

[29] Feldman, D. Gagnon, J. Hoffmann, R. and Simpson, J. (1988). Stat view IM.IIV.1.02. The solution for data analysis and presentation graphics, 189.

[30] Gram, L. and Melchiorsen, J. (1996). Interaction between fish spoilage bacteria Pseudomonas sp. and Shewanella putrefaciens in fish extracts and on fish tissue. Journal of applied bacteriology, 80(6):589-595.

[31] Sugita, H. Shibuya, K. Shimooka, H. and Deguchi, Y. (1996). Antibacterial abilities of intestinal bacteria in freshwater cultured fish. Aquaculture 145:195-203.

[32] Gram, L. Løvold, T. Nielsen, J. Melchiorsen, J. and Spanggaard, B. (2001). In vitro antagonism of the probiont Pseudomonas fluorescens strain $\mathrm{AH} 2$ against Aeromonas salmonicida does not confer protection of salmon against furunculosis. Aquaculture 199: 1-11.

[33] Hamdan, H. Weller, D. M. and Thomashow, L. S. (1991). Relative importance of fluorescent siderophores and other factors in biological control of Gaeumannomyces graminis var. tritici by Pseudomonas fluorescens 2-79 and M4-80R. Applied and Environmental Microbiolology 57:3270-3277.

[34] Shanahan, P. Osullivan, D. J. Simpson, P. Glennon, J. D. and Ogara, F. (1992). Isolation of 2, 4-diacetylphloroglucinol from a fluorescent pseudomonad and investigation of physiological parameters influencing its production. Applied and Environmental Microbiology 58:353-358.

[35] Loper, J. E. and Buyer, J. S. (1991). Siderophores in microbial interactions on plant surfaces. Molecular PlantMicrobe Interactions 4:5-13

[36] Fgaier, H. and Eberl, H. (2010). A competition model between Pseudomonas fluorescens and pathogens via iron chelation. Journal of Theoretical Biology 21, 263(4):566578 .

[37] Nair, S. and Simidu, U. (1987). Distribution and significance of heterotrophic marine bacteria with antibacterial activity. Applied and Environmental Microbiology 53(12):2957-296.

[38] Champomier-Verges, M. C. and Richard, J. (1994). Antibacterial activity among Pseudomonas strains of meat origin. Letters in Applied Microbiology 18:18-20.

[39] Vijayan, K. K. Singh, I. S. B. Jayaprakash N. S. Alavandi, S. V. Pai, R. Preetha, S. S. Rajan, J. J. S. and Santiago, T. C. (2006). A brackish water isolate of Pseudomonas PS-102, a potential antagonistic bacterium against pathogenic vibrios in penaeid and non-penaeid rearing systems. Aquaculture 251(2-4):192-200.

[40] Radjasa, O. K. Salasia, S. I. O. Sabdono, A. Weise, J. Imhoff, J. F. Lammer, C. \& Risk, M. J. (2007). Antibacterial activity of marine bacterium Pseudomonas sp. associated with soft coral Sinularia polydactyla against Streptococcus equi subsp. zooepidemicus. International Journal of Pharmacology, 3(2), 170-174.

[41] Alim, I. and Yuto, K. (2009). Bioactive substances produced by marine isolates of Pseudomonas. Journal of Industrial Microbiology and Biotechnology 36(10):1239-1248. 
[42] Uzair, B. Ahmed, N. Kousar, F. and Edwards, D. H. (2006). Isolation and characterization of Pseudomonas strain that inhibit growth of indigenous and clinical isolates. The Internet Journal of Microbiology, 2(2).

[43] Ongena, M. Jourdan, E. Adam, A. Schaefer, M. Budzikiewicz, H. and Thonart P (2008). Amino acids, iron, and growth rate as key factors influencing production of the Pseudomonas putida BTP1 benzylamine derivative involved in systemic resistance induction in different plants. Microbial Ecology 55:280-292.

[44] Aly, S. M. Abd-El-Rahman, A. M. John, G. and Mohamed, F. M. (2008). Characterization of some bacteria isolated from
Oreochromis niloticus and their potential use as probiotics. Aquaculture 277:1-6.

[45] Alderman, D. J. and Hastings, T. S. (1998). Antibiotic use in aquaculture: development of antibiotic resistance-potential for consumer health risks. International Journal of Food Science and Technology 33:139- 155.

[46] Treves-Brown, K. M. (2000). Applied Fish Pharmacology. Kluwer Academic Publishers, Dordrecht, Netherlands, 2654. 